\title{
Autophagic response of higher plant cells to a prolonged period of sucrose deprivation
}

\author{
R. Bligny ${ }^{1}$, C. Roby ${ }^{2}, A$. Dorne $^{1}$ and R. Douce ${ }^{1}$ \\ CEN-G and Université Joseph-Fourier, DRF/PCV ${ }^{1}$ and DRF/RMBM ${ }^{2}, 85 X, F-38041$, Grenoble \\ Cedex, France
}

\section{Introduction}

One of the most original properties of higher plant metabolism lies in the great flexibility of their adaptation processes when faced with variable environmental conditions. Thus, sudden temperature drop, water stress or the decrease of the circadian light period diminishes the rates of intracellular carbohydrate biosynthesis. Consequently, the supply of organic carbon necessary for sustaining cell respiration may be decreased. However, plant cells, owing to the presence of intracellular pools of carbohydrate and to their ability to control an autophagic process can survive for a period of several days without synthesizing or receiving any additional organic carbon. Some morphological observations have shown that, in higher plant cells, portions of the cytoplasm, including cell organelles such as mitochondria, may be engulfed by the tonoplast membrane (for a review, see Matile and Wiemken, 1976). In this study, we try to biochemically characterize the changes occurring in higher plant cells after a prolonged period of sucrose deprivation followed by a period of recovery.

\section{Materials and Methods}

Sycamore (Acer pseudoplatanus L.) cells were grown in a nutrient medium as described previously (Bligny, 1977) except $\mathrm{Mn}^{2+}$ was excluded to prevent excessive broadening of the vacuolar $31 \mathrm{P}$ orthophosphate resonance in $31 \mathrm{P}$ nuclear magnetic resonance (NMR) experiments. Cells harvested from the culture medium were rinsed 3 times by successive resuspensions in fresh culture medium devoid of sucrose and incubated in flasks containing sucrose-free culture medium. Every 5 or $10 \mathrm{~h}$, cells were harvested for perchloric acid (PCA) extraction (Roby et al., 1987), sucrose and starch determinations (Journet et al., 1986) and fatty acid + phospholipid measurements (Dorne et al., 1987).

31P NMR spectra of sycamore cells were obtained with a Bruker WM200 spectrometer operating in the pulsed-Fourier transform mode at $81 \mathrm{MHz}$. The spectra were obtained with compressed cells $\left(4 \mathrm{~cm}\right.$ in height, $3 \times 10^{8}$ cells, $9 \mathrm{~g}$ wet weight) placed in a $25 \mathrm{~mm}$ tube under constant perfusion as described by Roby et al., (1987). The perfusate consisted of culture medium devoid of phosphate, manganese and sucrose and was adjusted to $\mathrm{pH} 6.5$. In vivo spectra were obtained at $25^{\circ} \mathrm{C}$ after 3000 accumulations with a repetition time of $0.6 \mathrm{~s}$ and a pulse angle of $45^{\circ}$.

31P NMR spectra of PCA extracts stabilized at $\mathrm{pH} 7.5$ with $40 \mathrm{mM}$ HEPES buffer were measured on a Bruker AM400 spectrometer equip- 
ped with a $10 \mathrm{~mm}$ multinuclear probe tuned at $162 \mathrm{MHz}$. The deuterium resonance of $\mathrm{D}_{2} \mathrm{O}$ was used as a lock signal. Each spectrum represents the accumulation of 2048 free induction decay (FID) broad-bands, proton-decoupled, recorded with a sweep-width of $6000 \mathrm{~Hz}$, a $60^{\circ}$ pulse angle and a repetition time of $4 \mathrm{~s}$. The PCA extract spectra were referenced to the position of the $85 \% \mathrm{H}_{3} \mathrm{PO}_{4}$ resonance using a sample of $180 \mathrm{mM}$ methylene diphosphonic acid (in $30 \mathrm{mM}$ Tris buffer at $\mathrm{pH} \mathrm{8.9)} \mathrm{located} \mathrm{in}$ a coaxial capillary tube (outer diameter, 1.5 $\mathrm{mm}$ ). The attributions of the resolvable resonance rays were made after running a series of spectra obtained by addition of the authentic compounds to the PCA extracts. Cytochrome oxidase, polar lipids and cardiolipin measurements were carried out according to Bligny and Douce (1980).

Mitochondria were isolated from sycamore cell protoplasts and purified as described by Nishimura et al., (1982) using discontinuous Percoll gradients. The mitochondria subsequently concentrated by differential centrifugation were better than $95 \%$ intact as judged by their impermeability to cytochrome $c$ (Douce et al., 1972).

Sycamore cell respiration was measured at $25^{\circ} \mathrm{C}$ in their culture medium (Bligny and Douce, 1976).

\section{Results}

Effect of sucrose starvation on the rate of $\mathrm{O}_{2}$ consumption by sycamore cells

For $24 \mathrm{~h}$ the respiration rate of cells deprived of sucrose was constant (Fig. 1). It then decreased with time. After $50 \mathrm{~h}$ of starvation, the rate of $\mathrm{O}_{2}$ consumption was decreased to less than $50 \%$ of that of normal growing cells. Similarly, the uncoupled rate of $\mathrm{O}_{2}$ consumption obtained after the addition of $2 \mu \mathrm{M}$ carbonyl cyanide $p$-trifluoromethoxyphenylhydrazone (FCCP) decreased after ca $24 \mathrm{~h}$ in the same ratio as the rate of respiration without uncoupler. Comparison of Figs. 1 and 2 indi-

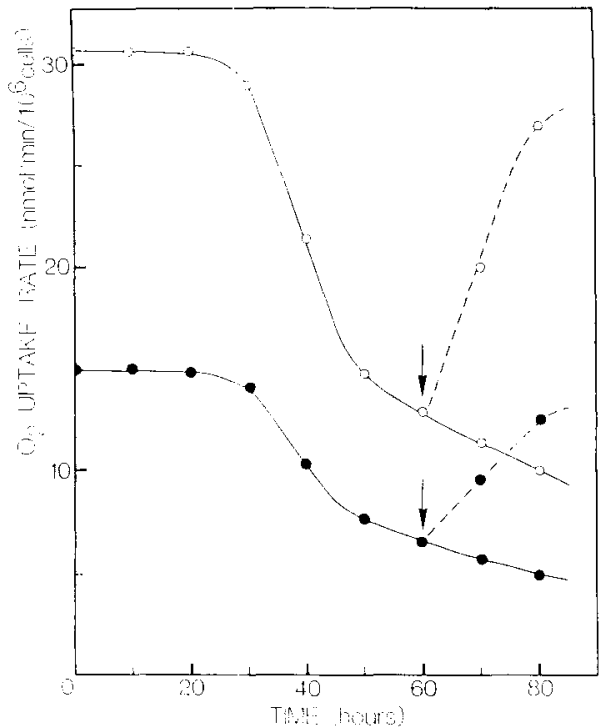

Fig. 1. Time course of sycamore cell respiration rate when cells were grown in a medium devoid of sucrose. Cells (20 $\mathrm{mg} \mathrm{FW}^{\mathrm{F}} \mathrm{ml}^{-1}$ ) harvested from the culture medium were rinsed 3 times by successive resuspensions in fresh culture medium devoid of sucrose and placed into flasks containing sucrose-free culture medium : normal respiration; $\mathrm{O}$ : uncoupled respiration; the broken line corresponds to the enhancement of cell respiration that is observable when $50 \mathrm{mM}$ sucrose is added to the culture medium (arrows).

cates that the rate of $\mathrm{O}_{2}$ consumption started declining when the intracellular sucrose had been consumed. At that stage, starch content was decreased to less than $30 \%$ of that of normal cells.

The fact that the rate of $\mathrm{O}_{2}$ consumption during sucrose starvation was always lower than the uncoupled rate (Fig. 1) suggested that, during all the experiments, the cell respiration rate was limited by the availability of ADP for either oxidative phosphorylation (Jacobus et al., 1982) or glycolysis (ap Rees, 1985) in plastids and cytosolic phase of sycamore cells. This was also suggested by the analysis of ${ }^{31} \mathrm{P}$ NMR spectra (see also Rebeillé et al., 1985, and Roby et al., 1987). 


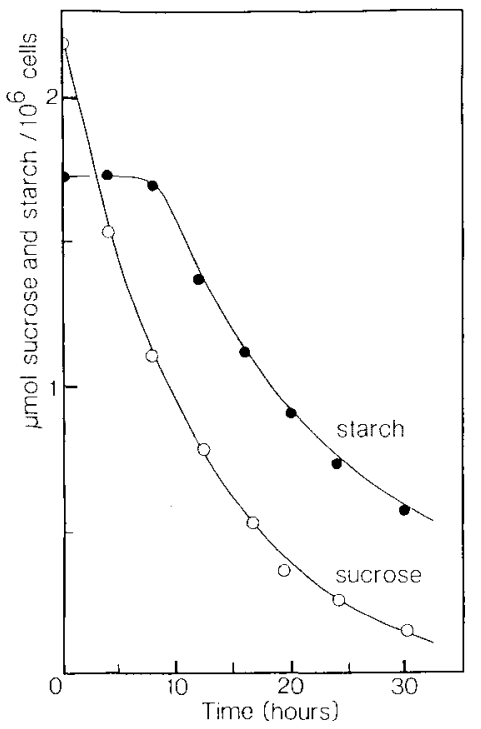

Fig. 2. Effect of sucrose starvation of sycamore cells on intracellular sucrose and starch levels. Cells harvested from the culture medium were rinsed 3 times by successive resuspensions in fresh culture medium devoid of sucrose and incubated at zero time $(45 \mathrm{mg}$ $\mathrm{FW} \cdot \mathrm{ml}^{-1}$ ) in flasks containing sucrose-free culture medium. The starch content is expressed as $\mu \mathrm{mol}$ of glucose $/ 10^{6}$ cells. For $10^{6}$ cells: Iresh weight $=28 \mathrm{mg}$; dry weight = $3.3 \mathrm{mg}$; protein $=0.55 \mathrm{mg}$.

\section{Effect of sucrose starvation on the level of $P$-esters in sycamore cells}

Figs. 3 and 4 illustrate the changes that occur in sycamore cells (31P NMR spectra) when sucrose was omitted from the nutrient medium. Cells were maintained for up to $80 \mathrm{~h}$ in a continuously oxygenated circulating solution ( $P_{\mathrm{i}}$-free culture medium) at $\mathrm{pH}$ 6.5. During the first $10 \mathrm{~h}$, little change occurred. Sucrose efflux from the vacuole was rapid enough to maintain an optimum phosphate ester concentration in the cytosol. After $10 \mathrm{~h}$ of sucrose starvation, the glucose 6-P resonance decreased progressively indicating that the sucrose efflux from the vacuole became a limiting factor for cytosolic glycoly-

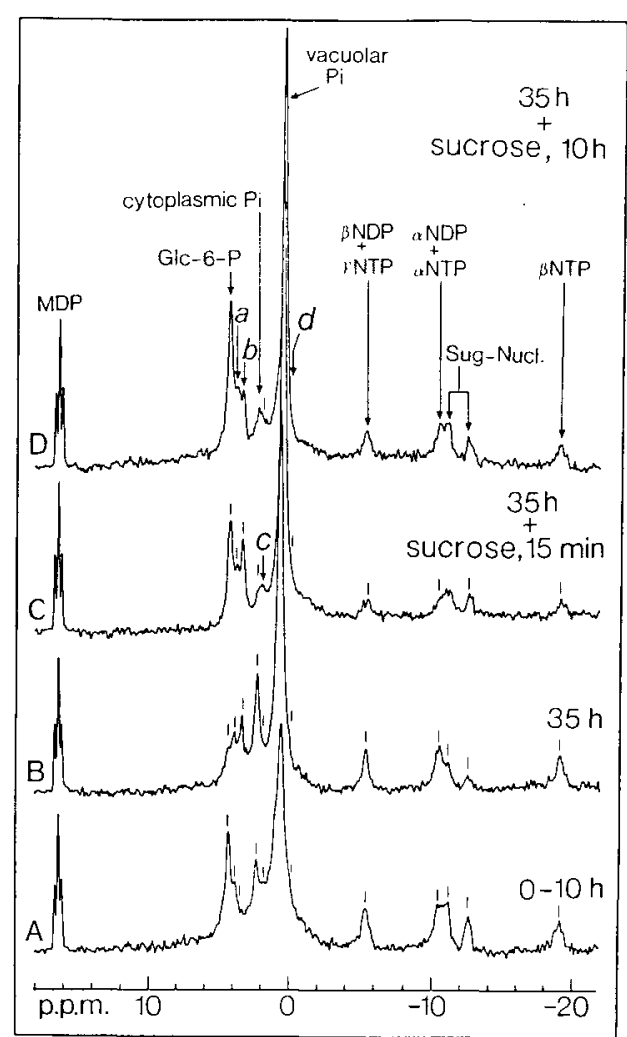

Fig. 3. Representative ${ }^{31} \mathrm{P}$ NMR spectra $(81 \mathrm{MHz})$ of sucrose-starved sycamore cells $(9 \mathrm{~g})$. Each spectrum recorded at $25^{\circ} \mathrm{C}$ represents the time average of 3000 free induction decays. A: spectrum from cells $10 \mathrm{~h}$ after initiating sucrose starvation. B: spectrum from cells after $35 \mathrm{~h}$ of sucrose starvation. C: recovery from $35 \mathrm{~h}$ of sucrose starvation $15 \mathrm{~min}$ after the addition of $50 \mathrm{mM}$ sucrose and $50 \mu \mathrm{M} \mathrm{P}_{\mathrm{i}}$ to the circulating medium. D: recovery from $35 \mathrm{~h}$ sucrose stanvation 10 $h$ after the addition of sucrose and $50 \mu \mathrm{M} \mathrm{P}_{\mathrm{i}}$. Peak assignments: Glc-6-P, glucose 6-P; $a$, position of fructose 6-P, ribose 5-P and P-ethanolamine; $b$, NMP and $P$-choline; cyt- $P_{i}$, cytoplasmic $P_{i} ; c$, position of glucose $1-P ; d$, position of phosphodiesters and myo-inositol hexakisphosphate. Positions for compounds not observed in the spectra of cells were assigned from the spectra of the extracts at pH 7.5.

sis (Rebeillé et al., 1985; Journet et al., 1986). During the period ranging from 10 to $35 \mathrm{~h}$, the $P_{i}$ molecules liberated from phosphate esters entered the vacuole where they accumulated $\left(P_{i}\right.$ accumulated 


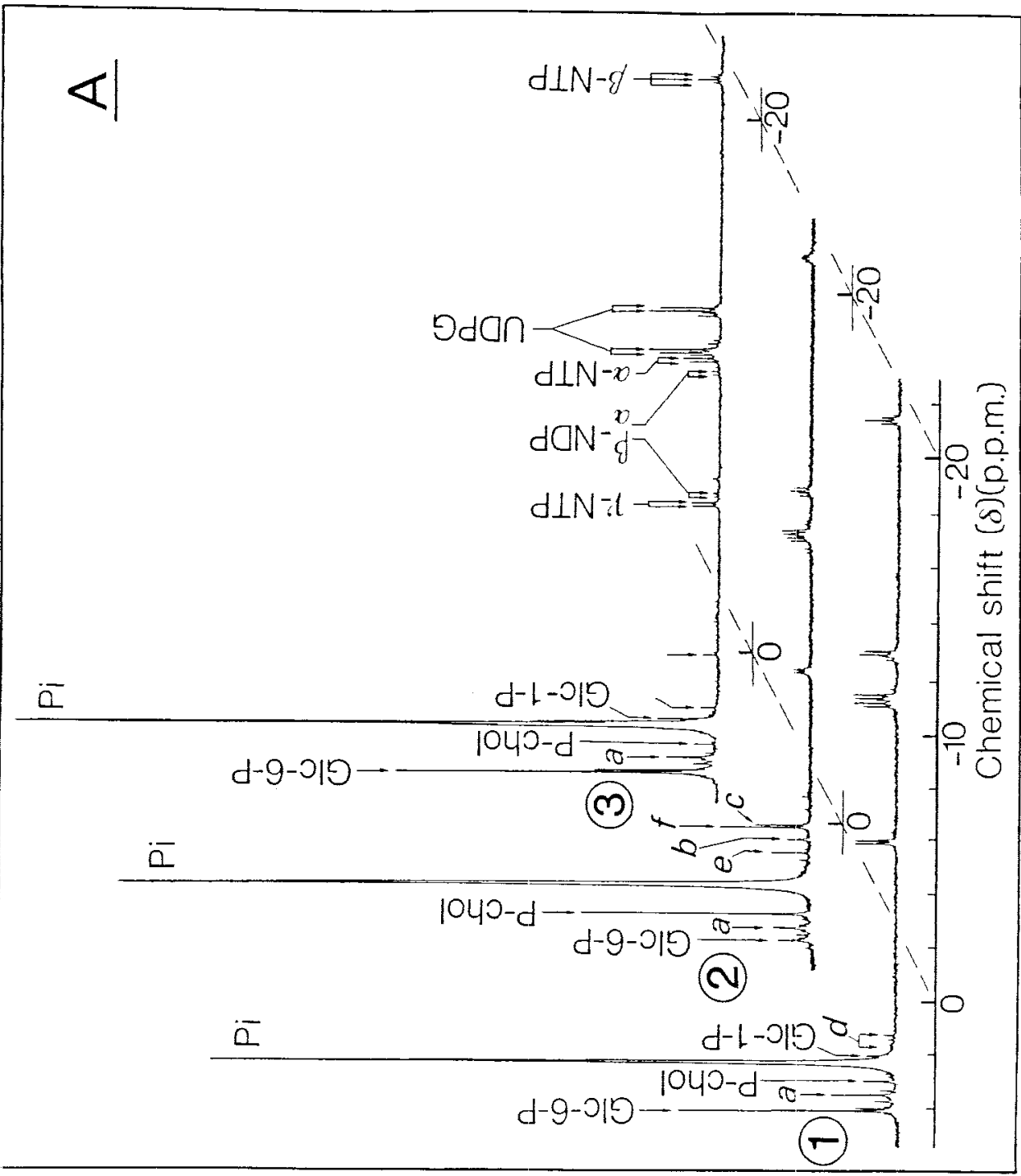

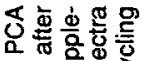

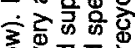
응 응 등

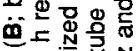
응음푹

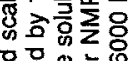
원유 ه은들

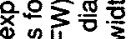

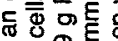
둥용ㅇㅎㅇ

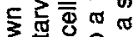

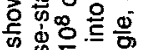

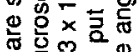

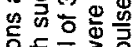
응두잉 숭요 은 뜽유 क柯产 혿홍응

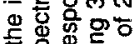

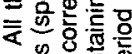

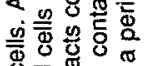
열 兽造 需 কั 은 융류 和至的

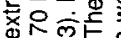
过元的宫 등 영응

(0) 웡을든 엉 응 क응 억웡웡 응놀 응 응 엉

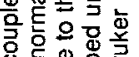
응원욘 응잉 응 공동

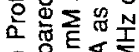
- 9 인 응ㄴㅇㅇㅇㅇ

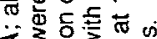
$\leq 3$

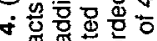

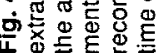


$801 s$

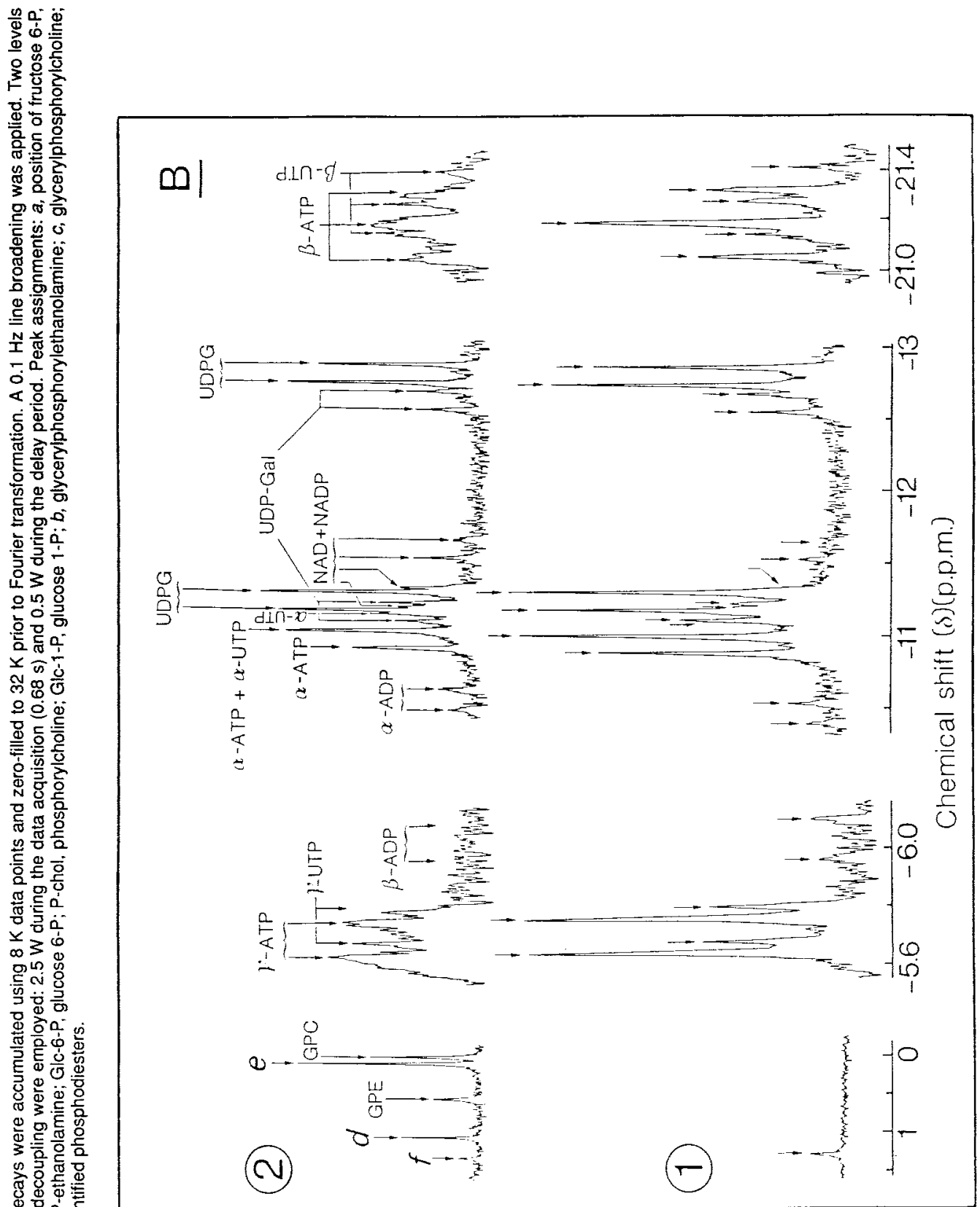

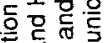

응-

응흐뭉

온

는은 웅 

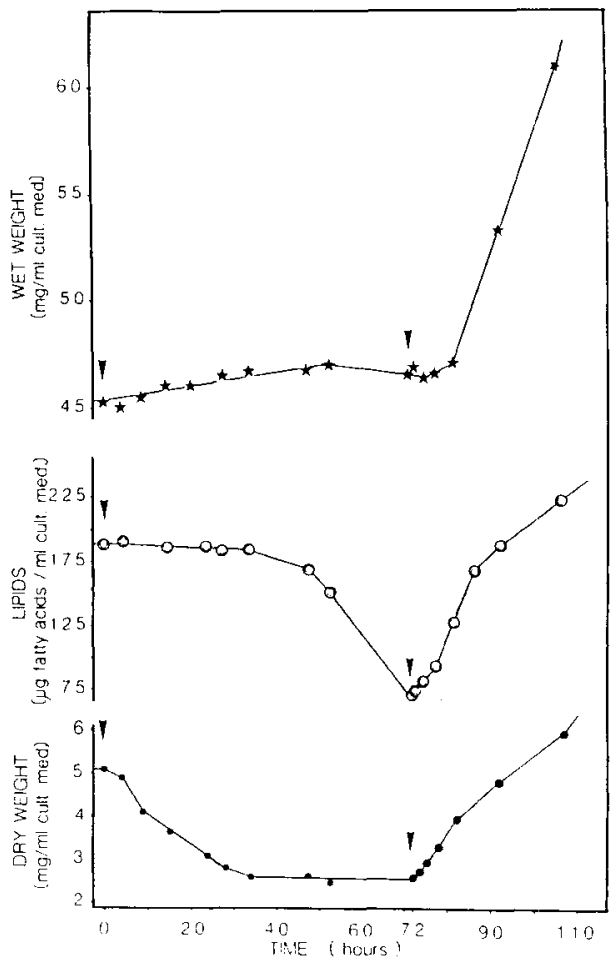

Fig. 5. Effect of sucrose starvation and replenishment on cell weight (fresh and dry weights) and on intracellular fatty acid content of sycamore cells. Cells were prepared as indicated for Fig. 2. At intervals, cells were harvested on a fiberglass filter (15 s; pressure of suction, 0.2 bar) to ascertain cell fresh weight. Cell dry weight was measured after lyophilization of the preceding samples. At the arrow, $50 \mathrm{mM}$ sucrose was added to the culture medium. The complete oxidation of 1 glucose molecule requires $6 \mathrm{O}_{2}$ (Beevers, 1961) and sycamore cells exhibited an $\mathrm{O}_{2}$ uptake rate of 42 nmol of $\mathrm{O}_{2} \cdot \mathrm{mg}^{-1} \mathrm{FW}$ (Rebeille et al., 1985). From the knowledge of both these parameters, one can calculate that $1.26 \mu \mathrm{g}$ of glucose $\mathrm{h}^{-1} \cdot \mathrm{mg}^{-1} \mathrm{FW}$ was required in order to sustain the respiration rate of sycamore cells. This value matches the measured rate of dry weight diminution $\left(1.5 \mu \mathrm{g} \cdot \mathrm{h}^{-1} \cdot \mathrm{mg}^{-1} \mathrm{FW}\right)$.

slightly in the cytoplasm). Surprisingly, the decreased glucose 6-P concentration was not accompanied by a parallel decrease in the concentration of nucleotide triphosphate (NTP) (Fig. 3). This indicated that, during the first $35 \mathrm{~h}$ of sucrose deprivation in higher plant cells, the adenylate energy charge (Pradet and Raymond, 1983) was maintained at a high level. When the sucrose deprivation was prolonged after $35 \mathrm{~h}$, i.e., when almost all intracellular sucrose and starch had been consumed, the amount of NTP in the cell decreased progressively. However, this decrease of NTP was not accompanied by a parallel increase in iritracellular NDP and NMP (Fig. 4).

The NTP/NDP ratio was maintained at a high value and it was possible therefore that the total amount of NTP per unit volume of cytoplasm might be maintained if the total cytoplasmic volume dropped sharply. Fig. 4 also shows that, after $35-40 \mathrm{~h}$ of sucrose starvation, there was a marked increase of glycerylphosphorylcholine (GPC), glycerylphosphorylethanolamine (GPE) and P-choline. Titration curves plotting chemical shift versus $\mathrm{pH}$ for P-choline in solutions of various compositions indicated that peak $b$ (Fig. 3) corresponded to P-choline above $\mathrm{pH} 7.5$, indicating that $\mathrm{P}$-choline accumulated in the cytoplasmic compartment. Finally, since GPE, GPC and P-choline can be considered as deriving from the most abundant polar lipids (phosphatidyl ethanolamine, $P E$, and phosphatidyl choline, PC) of sycamore cell membranes, this suggested that membrane systems were hydrolyzed during sucrose starvation to provide substrates for energy metabolism.

\section{Effect of sucrose starvation on cell weight and polar lipids of sycamore cells}

When sucrose was omitted from the nutrient medium, the cell wet weight per $\mathrm{ml}$ of culture medium appeared to be constant for at least $70 \mathrm{~h}$ (Fig. 5), whereas the dry weight decreased to $50 \%$ of the control value within the first $30 \mathrm{~h}$. This decline was attributable to the disappear- 
Table I. Cytochrome oxidase and cardiolipin contents of sycamore cells (normal and sucrosestarved) and sycamore cell mitochondria (normal and sucrose-starved).

\begin{tabular}{|c|c|c|c|c|}
\hline \multirow[t]{2}{*}{ Mitochondrial marker } & \multicolumn{2}{|l|}{ Cells } & \multicolumn{2}{|l|}{ Mitochondria } \\
\hline & $\begin{array}{l}\text { normal } \\
\\
(p m o l / 1\end{array}$ & $\begin{array}{l}\text { sucrose-starved } \\
\text { cells) }\end{array}$ & $\begin{array}{l}\text { normal } \\
\quad(n m o l / m g\end{array}$ & $\begin{array}{l}\text { sucrose-starved } \\
\text { rotein) }\end{array}$ \\
\hline $\begin{array}{l}\text { Cytochrome } a a_{3} \\
\text { Cardiolipin }\end{array}$ & $\begin{array}{r}13 \pm 2(6) \\
1050 \pm 150(6)\end{array}$ & $\begin{array}{r}5.8 \pm 1.5(4) \\
520 \pm 80 \quad(4)\end{array}$ & $\begin{array}{c}0.35 \pm 0.02(6) \\
29 \quad \pm 2 \quad(6)\end{array}$ & $\begin{array}{ccc}0.35 & \pm 0.03(4) \\
27 & \pm 2\end{array}$ \\
\hline
\end{tabular}

Normal cells: growing cells were harvested from the culture medium. Sucrose-starved cells and normal cells were rinsed 3 times by successive resuspensions in fresh culture medium devoid of sucrose and incubated for $50 \mathrm{~h}$ in flasks containing sucrose-free culture medium. Normal mitochondria: mitochondria from normal cells; sucrosestarved mitochondria: mitochondria from sucrose-starved cells. The SD is given for $95 \%$, the number of experiments is shown between parentheses.

ance of sucrose from the vacucle and starch from the plastids (see Fig. 2). During this time, the cell fatty acid content remained constant (Fig. 5). However, fatty acid content declined after $40 \mathrm{~h}$ of sucrose starvation, when almost all the intracellular carbohydrate pool had disappeared. Analysis of cell phospholipids indicated that $\mathrm{PC}$ and $\mathrm{PE}$, which represent respectively $40-45 \%$ and $25-27 \%$ of the cell polar lipids (Bligny and Douce, 1980), decreased to $30 \%$ of the control value within $70 \mathrm{~h}$ of sucrose starvation. Similarly, the galactolipids and the total protein (including the enzymes of the glycolytic pathway in cytosol) decreased in the same proportion during the starvation period (Journet et al., 1986).

Under these conditions, the decrease in the uncoupled rate of $\mathrm{O}_{2}$ consumption during the course of sucrose starvation could be attributable to a progressive diminution of the cytoplasmic compartment and particularly to a diminution of the number of mitochondria per cell. Since we have already demonstrated that, in higher plant cells, cardioplipin and cytochrome $\mathrm{aa}_{3}$ are exclusively localized in the mitochondrial inner membrane (Bligny and Douce, 1980), we measured the levels of these 2 specific mitochondrial markers during sucrose starvation.
Quantitative determination of cytochrome $\mathrm{aa}_{3}$ and cardiolipin in sycamore cell mitochondria

The values for cytochrome $a_{3}$ and cardiolipin contents in sycamore cells and sycamore cell mitochondria are given in Table 1. Data indicated that cytochrome $a a_{3}$ and cardiolipin contents of mitochondria isolated from sycamore cells were constant during sucrose depletion. In contrast, they declined to less than half of the normal value after $50 \mathrm{~h}$ of sucrose starvation. It is noteworthy that the lag phase observed for cardiolipin or cytochrome $\mathrm{aa}_{3}$ evolution (Fig. 6) was comparable to that observed for $\mathrm{O}_{2}$ uptake evolution (Fig. 1). Furthermore, comparison of Figs. 1 and 6 indicates that the respiration rates decreased progressively in the same ratio as the decrease in intracellular cardiolipin or cytochrome $a_{3}$. In addition, it was established that: 1) on a protein basis, the rate of $\mathrm{O}_{2}$ uptake in state 3 was about the same for normal and sucrose-starved mitochondria (Journet et al., 1986); 2) the mitochondrial structure and size were not modified by sucrose starvation (electron microscopy data not shown). In conclusion, all these results demonstrate that, after a long period of sucrose starvation, the progressive decrease in the uncoupled 


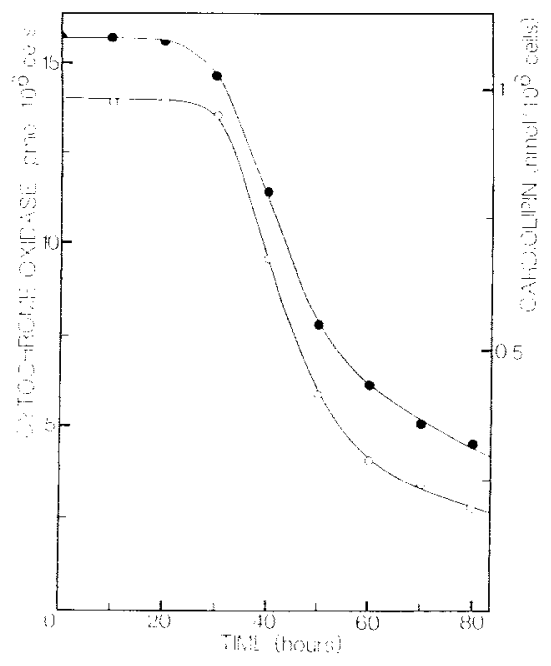

Fig. 6. Effect of sucrose starvation of sycamore cells on intraceltular cardiolipin (e) and cytochrome $\mathrm{aa}_{3}(\mathrm{O})$ contents. Cells were prepared as indicated for Fig. 1. At each time, cells were harvested and cardiolipin and cytochrome $a a_{3}$ contents were measured as described under Materials and Methods.

rate of $\mathrm{O}_{2}$ consumption by sycamore cells was attributable to a progressive diminution of the number of mitochondria per cell.

\section{Effect of sucrose replenishment}

Addition of $50 \mathrm{mM}$ sucrose to the nutrient medium after $35 \mathrm{~h}$ of sucrose starvation (i.e., just before the decline in the uncoupled rate of $\mathrm{O}_{2}$ consumption) resulted in a very rapid increase of glucose $6-P$ resonance accompanied by the disappearance of the cytoplasmic $P_{i}$ (Fig. 3). In order to increase further the intracellular concentration of glucose 6-P to its original level, it was necessary to add a small amount of $\mathrm{P}_{\mathrm{i}}(50 \mu \mathrm{M})$ to the circulating medium, since the efflux of $P_{i}$ from the vacuole was not sufficient to sustain rapid phosphorylation processes.
Addition of sucrose after $70 \mathrm{~h}$ of sucrose starvation resulted in a marked increase in the cell dry weight and total fatty acids (Fig. 5). The increase in the cell dry weight was attributable to a rapid accumulation of sucrose in the vacuolar reservoir and starch in plastids (not shown), whereas the increase in total cell fatty acids was attributable to the synthesis of new cytoplasmic material, such as mitochondria. Of particular interest was the marked decrease in the amount of P-choline that was reused for the synthesis of PC. Meanwhile, the cell respiration rates increased until the normal value was reached. Interestingly, the coupled respiration increased more rapidly than the uncoupled respiration during the first hours of recovery (Roby et al., 1987). This was attributable to the fact that such a rapid synthesis of cell metabolites transiently consumed high levels of ATP.

\section{Discussion}

These results demonstrate that the transfer of sycamore cells into a sucrose-free culture medium triggers the following cascade of reactions. 1) Initially, sucrose present in the vacuole was consumed. Then the glucose 6-P level declined progressively, liberating inorganic phosphate which could stimulate the phosphorolysis of starch. 2) When almost all the intracellular carbohydrate pools had disappeared, the cell fatty acids declined progressively with a paralle! increase in polar lipid deacylation products, such as P-choline. During this stage, the cell respiration rates declined as a consequence of the decrease in the number of mitochondria per cell. Similarly, the total amount of ATP per cell was reduced in the same proportions as cell lipids and proteins. However, the 
ATP/ADP ratio remained considerable, even after $70 \mathrm{~h}$ of sucrose starvation. The absence of relative accumulation of ADP in the cytoplasm explains the fact that the uncoupled/coupled respiration rate ratio remained constant throughout the experiment. Another interesting feature is that $P_{i}$ derived from hydrolyzed P-ester was rapidly accumulated in the vacuole after its cytoplasmic concentration increased to ca $40 \%$. 3) During the course of sucrose replenishment, carbohydrate and P-ester were resynthesized within $2-4 \mathrm{~h}$ and reached their standard cellular rate if external $P_{i}$ was added. In fact, $P_{i}$, which has previously been sequestered in the vacuole during the course of sucrose starvation, was not readily returned to the cytoplasm for metabolic processes. Thus, several groups (Rebeillé et al., 1983; Sivak and Walker, 1986; Martinoia et al., 1986) have already suggested that the homeostatic process of $P_{i}$ transport across the tonoplast is slow and allows short-term changes in the cytosolic $\mathrm{P}_{\mathrm{i}}$-pool size to be used as a means of regulating metabolic functions, such as starch and sucrose syntheses.

The results presented here also demonstrate that, during the course of sucrose replenishment, $P$-choline was reused for PC synthesis. It may therefore be concluded that the presence of excess of P-choline in plant cells should be considered as a good marker of membrane utilization after a long period of sucrose starvation and sucrose synthesis.

In conclusion, it appears that the plant cell metabolism is extremely flexible. The cytoplasm, in particular, can be utilized as a carbon source after a long period of sucrose starvation without significantly affecting the survival of the cell. Under these conditions, higher plant cells, owing to the presence of intracellular pools of carbohydrate and to their ability to control an autophagic process, can survive for a long time after the synthesis or the supply of organic carbon has been terminated.

\section{References}

ap Rees T. (1985) The organization of glycolysis and the oxidative pentose phosphate pathway in plants. In: Encyclopedia of Plant Physiology, Vol. 18, (Douce R. \& Day D.A., eds.), Springer-Verlag, Heidelberg, pp. 391-417

Beevers H. (1961) In: Respiratory Metabolism in Plants. Row, Peterson and Company, Evanston, IL, pp. 119-129

Bligny R. (1977) Growth of suspension-cultured Acer pseudoplatanus L. cells in automatic culture units of large volume. Plant Physiol. 59, 502-505

Bligny R. \& Douce R. (1976) Les mitochondries de cellules végétales isolées. Physiol. Vég. 14, 499-515

Bligny R. \& Douce R. (1980) A precise localization of cardiolipin in plant cells. Biochim. Biophys. Acta 617, 254-263

Dorne A.J., Bligny R., Rebeillé F., Roby C. \& Douce R. (1987) Fatty acid disappearance and phosphorylcholine accumulation in higher plant cells after a long period of sucrose deprivation. Plant Physiol. Biochem. 25, 589-595

Douce R., Christensen E.L. \& Bonner W.D. (1972) Preparation of intact plant mitochondria. Biochim. Biophys. Acta 275, 148-160

Jacobus W.E., Moreadith R.W. \& Vandegaer K.M. (1982) Mitochondrial respiratory control. Evidence against the regulation of respiration by extramitochondrial phosphorylation potentials or by ATP/ADP ratios. J. Biol. Chem. 257, 2397-2402

Journet E.P., Bligny R. \& Douce R. (1986) Biochemical changes during sucrose deprivation in higher plant cells. J. Biol. Chem. 261, 31933199

Martinoia E., Schramm M.J., Kaiser G., Kaiser W.M. \& Heber U. (1986) Transport of anions in isolated barley vacuoles. Plant Physiol. 80, 895901

Matile P. \& Wiemken A. (1976) Interactions between cytoplasm and vacuole. In: Encyclopedia of Plant Physiology, Vol. 3 (Stocking C.R. \& 
Heber U., eds.), Springer-Verlag, Heidelberg, pp. 255-287

Nishimura M., Douce R. \& Akazawa T. (1982) Isolation and characterization of metabolically competent mitochondria from spinach leaf protoplasts. Plant Physiol. 69, 916-920

Pradet A. \& Raymond P. (1983) Adenine nucleotide ratios and adenylate energy charge in energy metabolism. Annu. Rev. Plant Physiol. 34, 199-224

Rebeillé F., Bligny R., Martin J.B. \& Douce R. (1983) Relationship between the cytoplasm and the vacuole phosphate pool in Acer pseudopla- tanus cells. Arch. Biochem. Biophys. 225, 143148

Rebeillé F., Bligny R., Martin J.B. \& Douce R. (1985) Effect of sucrose starvation on sycamore (Acer pseudoplatanus) cell carbohydrate and $\mathrm{P}_{\mathrm{i}}$ status. Biochem. J. 226, 679-684

Roby C., Martin J.B., Bligny R. \& Douce R. (1987) Biochemical changes during sucrose starvation in higher plant cells. J. Biol. Chem. 262, 5000-5007

Sivak M.N. \& Walker D.A. (1986) Phosphosynthesis in vivo can be limited by phosphate supply. New Phytol. 102, 499-512 